\title{
Mental Health among Doctors and Advocates as Related To
}

\section{Their Working Spouses}

\author{
Dr. Vibha Nagar ${ }^{1 *}$, Dr. Manju Khokhar ${ }^{2}$
}

\section{ABSTRACT}

The Purpose of the present investigation is to find out the mental health of doctors and advocates. The study was conducted on a sample of 300 professionals (150 Doctors and 150 Advocates) drawn from Meerut District. Mental health was measured by Mithila Mental Health status Inventory (M.M.H.S.I.) developed by Kumar and Thakur (1986). The results were analysed with the help of ANOVA and t test, ANOVA revealed that profession and occupation of spouse cumulatively influences the mental health of professionals. It was found that doctors have better mental health as compared to advocates. In the same way doctors and advocates who have working spouse have better mental health as compared to those whose spouse are not working. Thus the findings have applied application for doctors and advocates.

Keywords: Mental health, occupation of spouse, profession, ANOVA

Study of mental health has been a challenging task for the psychologists, researchers and other professionals who practice in medical and counselling fields. Studies conducted on mental health during the last ten years have not brought to light any single factor or a group of factors that equally or consistently promote mental health of professionals. Barnett, (1992); Travers et al., (1993), found relationships between job stress and psychological distress. It is exacerbated among men who had troubled relationships with their partners. Zilli \& Zahoor (2012) and Chaudhary. (2009), conducted a research on females who were highly educated and the results revealed that higher education female teachers have greater organizational commitment as compared to higher education male teachers. And the level of life satisfaction was higher among women in terms of level of stress as compared to their counterparts.

The term 'Health' is a positive and dynamic concept that implies more than absence of illness. The World Health Organization (W.H.O.) 1951, has defined health as "Stat of complete physical, mental and social well-being and not mearly the absence of disease or infirmity". Eysenk (1972) stated about Mental Health" A State in which the need of individual and the claims of

\footnotetext{
${ }^{1}$ Post Doctoral Fellow Department of Psychology, Meerut College, Meerut

${ }^{2}$ Reader, Department of Psychology, Meerut College, Meerut

*Responding Author

(C) 2016 I V Nagar, M Khokhar; licensee IJIP. This is an Open Access Research distributed under the terms of the Creative Commons Attribution License (http://creativecommons.org/licenses/by/2.0), which permits unrestricted use, distribution, and reproduction in any Medium, provided the original work is properly cited.
} 
environment are fully satisfied or the power by which this harmonious relationship can be attained "The positive well being" as the criteria of mental health. This is an ideal state. Thus mental health has been viewed in terms of ideal rather than in terms of lack of disease (W.H.O. 1951). Review related of literature revealed that mental health is influenced by different factors in different situation. It is influenced not only by the needs, aspirations, personality factors but also by others socio-psychological and environmental factors, providing in the society that exist at a particular moment of time. Simen et al. (1995) explored gender differences in the consequences of combining spouse parent and worker roles for mental health it was found that work and family roles have different meaning for men and women. Not only gender but socioeconomic status is also an important variable that effects the mental health of professionals Goldenhar et al. (1998), illustrated that having responsibility for others safety, having support from supervisors and coworkers was related to greater job satisfaction.

Thus, on the basis of above studies psychologists realized the complexities associated with the study of mental health of professionals specially among doctors and advocates. Psychologists have realized the complexities associated with the study of mental health of professionals especially doctors and advocates.

\section{METHODOLOGY}

Objectives:- The objectives of the present investigation is to study the mental health of doctors and advocates. Another objective of the study is to study the mental health of doctors and advocates having working and non working spouses.

Hypothesis: On the basis of above objectives following hypothesis were formulated:

1. Doctors and advocates were significantly different in their mental health.

2. Doctors and advocates having working/non working spouses were significantly differ in their mental health.

3. Profession of spouse will cumulatively influence the mental health of subjects.

Sample:- The sample of the present study consists of 300 professionals. 150 doctors and 150 advocates comparing both working and non working spouses between the age range of 30 to 50 .

Table-I, Characteristic of the Sample

\begin{tabular}{|c|c|c|c|c|}
\hline Groups & M & F & Age Range & Experience \\
\hline Doctor(150) & 115 & 35 & 30 to 50 yrs & 1 to 20 yrs \\
\hline Advocates(150) & 115 & 35 & 30 to 50 yrs & 1 to 20 yrs. \\
\hline
\end{tabular}

Tools: In present research investigation Mithila Mental Health Status Inventory (M.M.H.S.I.) developed by Kumar and Thakur (1986) was used for measuring the mental health of professionals and their spouses (Working and Non working). Higher scores in the inventory refers to the poor mental health. Its reliability is .90 by split half method and validity is 
statistically significant by comparison method.

\section{RESULTS}

The data was analysed with the help of ANOVA and ' $t$ ' test. The results obtained by test are given in the following tables.

Table-II, Analysis of Variance Mental Health Status Among Professinals

\begin{tabular}{|c|c|c|c|c|}
\hline Source & S.S. & d.f. & M.S.S. & F. ratio \\
\hline $\begin{array}{c}\text { Doctor \& } \\
\text { Advocates (A) }\end{array}$ & 236.31 & 1 & 236.31 & $34.26^{* *}$ \\
\hline $\begin{array}{c}\text { Working /Non } \\
\text { Working Spouse } \\
(\mathrm{B})\end{array}$ & 16.05 & 1 & 16.05 & $2.33^{*}$ \\
\hline $\mathrm{A} \times \mathrm{B}$ & 32.15 & 1 & 32.15 & \\
\hline Error & 2039.44 & 296 & 6.89 & $4.66^{* *}$ \\
\hline Total & 323.95 & 299 & & \\
\hline
\end{tabular}

* significant at 0.01 level of significance

The above table depicted that profession and spouse exert significant effects on mental health of subjects. The interaction value is also significant at 0.1 level of significance. On the basis of above table we can say that profession and spouse has cumulative effect on the mental health of subjects. Sharma et al. 2009; Tomar et al. 2009 and Rani (2009) found a negative relationship between stress and life satisfaction as well as self esteem and stress but positive relationship was found between self-esteem and life satisfaction.

't'- test was also used to find out the significant differences between the groups.

Table-III, Comparison of Mental Health between Doctors and Advocates

\begin{tabular}{|c|c|c|c|c|}
\hline $\begin{array}{c}\text { Groups } \\
\text { Compared }\end{array}$ & $\mathbf{N}$ & Mean & S.D. & t-value \\
\hline Doctor & 150 & 124.84 & 11.42 & \multirow{2}{*}{$6.87^{* *}$} \\
\hline Advocates & 150 & 131.033 & 12.55 & \\
\hline
\end{tabular}

** Significant at .01 level of significance.

The above table confirms that there is significant difference between mental health of doctors and advocates. From the table it can be inferred that doctors have better mental health as compared to advocates. The mean value on mental health of doctors $(m=124.84)$ and mean value of advocates on mental health is $(\mathrm{m}=131.03)$ and ("SD-11.42 and 12.55") respectively. From these value it is assumed that higher the mean on mental health, poorer is the mental health of professionals. On the basis of these results we can say that doctors have better mental health as compared to advocates. 
Mental Health among Doctors and Advocates as Related To Their Working Spouses

Tale-IV, Comparison of Mental Health of professionals having working and non working spouses

\begin{tabular}{|l|c|c|c|c|}
\hline \multicolumn{1}{|c|}{ Groups Compared } & N & Mean & S.D. & t-value \\
\hline Working Spouse (Doctors \& Advocates & 135 & 124.30 & 10.44 & \multirow{2}{*}{$3.08^{* *}$} \\
\cline { 1 - 4 } $\begin{array}{l}\text { Non-working spouse(Doctors \& } \\
\text { Advocates) }\end{array}$ & 165 & 128.30 & 12.15 & \\
\hline
\end{tabular}

**Significant at .01 level of significance

The above table depicts that occupation of spouses (working/non-working) significantly influences the mental health of professionals. The mean value of mental health of those professionals who have working spouse have better mental health (Mean 124.30 and SD 10.40) as compared to the mean value of professionals whose spouses were not working (Mean 128.30 and SD 12.15). Higher mean value showed poor mental health of professionals. Thus, we can say that doctors and advocates whose life partners were working have better mental health as compared to those whose life partners are not working.

Mansuri (2008) found that married working women have better mental health, private and public sector working women were the same on mental health, and Sharma, (2009) found a significant difference in the level of stress between working and non-working women. As Tripathi et al. (2008) stated that cognition functions of working women are greater than nonworking women.

Doctors and advocates constitute the institutions of specialist. It is forcefully argued by expert of human resources development that specialization in a particular skill is a important component of individual. Doctors and advocates differ in their mental health because of their intellectual abilities, Jobs differ in the demand they place on them to use their intellectual abilities, capabilities, talents and also their expertize are important moderators perform their work successfully specially for doctors.

\section{DISCUSSION}

James (1999); found a negative relationship between daily stress, intimacy and marital quality and a degree of anxiety etc. Sareen (2009) tried to identify the factors that affect mental health of employers and suggested that some strategies and could create a happy work place.

On the other hand advocates and lawyers want simple answers to complicated human questions and insist to seek them even when they may not best describe the truth. It is because they come from near by villages, towns to do their work and usually return to their native places after duty. They look after their ancestoral properties. Thus their involvement in legal work is tangible and any out side interest may be more uncreative. Bruke et al. (2004) investigated a sample of 776 police officers with a spouse or partner in the same profession, and both have reported significantly lower concern for spouse Perrone \& Kristin, (2005) highlighted information for 
career counsellors when they were addressing work family interface with individuals who have members of same, sex, dual earner couples or families.

In doctors the feeling of confidence, self-assurance, self-motivation, perhaps self intrinsic satisfaction, which doctors acquired by his/her occupation helps in festering better mental health. Doctors have greater freedom of action. They themselves possess their authority for scheduling the work and taking decisions for the execution of their tasks. In this regards advocates can only play the role of obeying the orders and not to take decisions on their own. Such aspects are found to influence the mental health, which is amply, reflected in our findings where doctors have better mental health as compared to advocates. As Sharma et al. (2009), demonstrated that type of profession is a strong cause of positive and negative mental health supported above stated findings.

While interpreting that professional with working spouse overall have better mental health as compared to professionals with no working spouse. We found the cause behind this is due to earning of their counterpart. Professionals have good adjustment, flexibility to expenditure and same educational level. They feel secure about their future due to dual income, they have luxurious life with all comforts. They have freedom of taking decisions and face challenges of life. Because of these aspect professionals have better mental health as compared so those who have none working spouse. Hence our findings are supported with the findings of Rosen \& price (2001); Roundoft et al (2002) : Rosenlnal and Price (2001), these researchers have found that status of spouse is closely related to the economic position for better mental health among doctor and advocates.

\section{CONCLUSION}

On the basis of above discussion, it can be summarized that Doctors and advocates who have working spouse have better mental health as compared to those whose spouses are not working. In this concern finding have applied applications for doctors and advocates according to some intervention strategies can be evolved to promote better mental health. Among doctors and advocates who have no working spouse.

\section{REFERENCES}

Barnett, R.; Marshall, C.; Nancy, L. (1992). Men's Job and Partner Roles: Spillover Effects and Psychological Distress. Research on Women, 27(9-10); 455-472.

Bruke, R.; Mikkelsen, J.; Aslaug, (2005). Benefits to Police of Having a Spouse or Partner in the Profession of Police Officers. Psychological Reports, 92 No. 6.

Chaudhary, S. (2009). Life Satisfaction and Stress Among Working Women and Housewives. Department of Psychology.K.G. K.(P.G.) College, Moradabad. Souvenir, National Seminar on Mental Health and Current Scenario.

Eysenk, H.J. (1972). A Note on "Factors Influencing the Outcomes of Psychotherapy Psychological Bulletin. 78, 403-405. 
Goldenhar Linda, M.; Naomi, S.; Hurrell, G.; Joseph, Jn.; Avima, R.; James, D. (1998). National Institute for Occupational Safety and Health, Cincinnati, O.H. U.S. Journal of Occupational and Health Psychology. 3(1), 19-32.

James, K.(1999). Re-Thinking Organizational Stress: The Transmission to the New Employment Age. Journal of Management Psychology, 14.(718), 545-557.

Kumar, A. Thakur, G.P. (1986). Muthila Mental Health Status Inventory (MMHSI). Department of Psychology, Kashi Vidyapith University, Varanasi; Ganga Saran \& Grand Sons.

Mansuri, M.G. (2008). Mental Health of Married and Unmarried Working of Different Organization in Relation to Family Environment. Indian Journal of Psychology and Mental Health, 2. No. 3.

Perronl. Kristin, M.; (2005). Work Family interface for Same-Sex, Dual Earner Couples. Emplications for Counsellors Career Development Quarterly. Jan., Vol. 53(4), 317-324.

Rani, S. (2009). Mental Health of the Working and Non Working Women in Relation to Their Marital Status. Department of Psychology, Gurukul Kangari University, Haridwar (U.K.). Souvenir, National Seminar on Mental Health and Current Scenario. March $20^{\text {th }}$ $21^{\text {st }}$

Rosenlhal, G.T.; Macknight, R.; Price, A.W. (2001). Who What Knows How and Where the Typical Psychologist is......the Profession of Psychology Scale. Journals of Instrumental Psychology. 28(4), 220-224.

Roudolf, S.; Hortan, A.,; Macneil, J.R. (2001). Drived Trial Making Test Indcies in Sample of Substance Abuse: Demograhic Effects. International Journal of Neuroscience, Vol. 3. (1-2) (123-132).

Sareen, R. (2009). Yoga and Mental Health Department of Psychology, C.C.S.University, Meerut. Sourvenir National Seminar of Mental Health and Current Scenario, March $20^{\text {th }}-21^{\text {st }}$

Sharma, G.; Kumari, P. (2009). Stress, self esteem and Life Satisfaction Among Married Teachers. Dayalbagh Educational Institute, Dayalbagh Agra Souvenir National Seminar on Mental Health and Current Scenario.

Sharma, V. (2000). "A Study of Mental health of Working and Non Working Women" Unpublished M.Phil Dissertation Meerut : C.C.S.University,

Simon; Robin,W. (1995). Gender, Multiple Roles, Role Meaning and Mental Health. U.; IOWA, Department of Sociology, IOWA City , U.S. Journal of Mental and Social Behaviour, 36(2): 182-184.

Tomar, S. Gupta, N. (2009). Predictors of Mental Health Among Dual Carrier Couples Across Life. Satisfaction. Department of Psychology, D.A.V.(P.G.) College, D.Dun. Souvenir, National Seminar on Mental Health and Current Scenario. March $20^{\text {th }}-21^{\text {st }}$

Travers; Cherye, J.; Cary, C.P. (1993). Mental Health Job Satisfaction \& Occupational Stress Among U.K. Teachers. London Business School. Ctr. for Organizational Research, England Work and Stress. 7(3): 203-219.

Tripathi, M.N.; Vikas, R.M. ; Tripathi \& Tripathi, P. (2008). Working Women: Psychological Problems. Indian Journal of Psychology and Mental Heatlh. 2. No. 3. 
W.H.O.(1951). Mental Health and Mental Illness Word of Today Feature Series. 7, April Zilli, S.A.; Zahoor, Z. (2012). Organizational Commitment Among Male and Female Higher Education Teachers Department of Psychology, A.M.U Aligarh. Souvenir, National Seminar on Mental Health and Current Scenario. March $20^{\text {th }}-21^{\text {st }}$

How to cite this article: V Nagar, M Khokhar (2016), Mental Health among Doctors and Advocates as Related To Their Working Spouses, International Journal of Indian Psychology, Volume 3, Issue 3, No. 8, DIP: 18.01.144/20160303, ISBN: 978-1-365-12176-0 